\title{
ROLE OF ORGANIZATIONAL STRUCTURE ON CONSTRUCTION WASTE MANAGEMENT AMONG KUANTAN MALAYSIAN CONSTRUC- TION INDUSTRIES
}

\author{
F. Kamarosisam ${ }^{1}$, A. Q. Adeleke ${ }^{1}$ and T.T. Taiwo ${ }^{2}$ \\ ${ }^{1}$ Faculty of Industrial Management, Universiti Malaysia Pahang, Lebuhraya Tun Razak, 26300 Gambang, Pahang, Malaysia \\ ${ }^{2}$ School of Accounting and Finance, University of East London, England
}

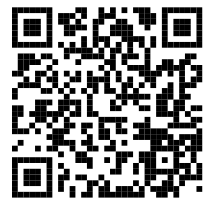

School of Accounting and Finance, University of East London, England

Check for
updates

Received 5 June 2021

Accepted 17 June 2021

Published 12 July 2021

Corresponding Author

A. Q. Adeleke, adekunle@ump.edu. my

DOI $10.29121 /$

IJOEST.v5.i4.2021.199

Funding: This research received no specific grant from any funding agency in the public, commercial, or not-for-profit sectors.

Copyright: (C) 2021 The Author(s). This is an open access article distributed under the terms of the Creative Commons Attribution License, which permits unrestricted use, distribution, and reproduction in any medium, provided the original author and source are credited.

\section{ABSTRACT}

The construction industry is one of the sectors contributing to the Malaysian economy and is regarded as an important component of the Malaysian economy. At the same time, as the number of building projects rises, the amount of waste created by building projects also increases, which also has many negative effects on the environment and public health. To reduce the amount of waste created by construction projects, waste must be properly handled and effective practices in the management of construction waste must be implemented in all construction industries. This research paper aims to answer these problems above in order to: 1) to investigate the relationship between formalization structure and construction waste management in Pahang construction industries; and 2) to investigate the relationship between centralization structure and construction waste management in Pahang construction industries. Data were obtained from 107 respondents among construction companies in Pahang. The PLS-SEM technique was used to test both the measurement and structural models in this analysis. The outcome shows that there is an important connection between the formalization structure and the management of construction waste among the construction companies operating in Pahang. The structure of centralization and waste management for construction was also found to be positively associated in this study.

Keywords: Organizational Structure, Construction Waste Management, Formalization, Centralization, Kuantan, Pahang

\section{INTRODUCTION}

The construction industry indeed continues to be a heavily labour - intensive sector and it is therefore apparent that the dominant culture in the industry is one of the key factors for the weak productivity in the industry (Denison, 1984) , (Gordon and 
DiTomaso, 1992), Liu et al. (2006), Gregory et al. (2009), Nukic (2018). Construction sectors appear to be people-centered, unlike the manufacturing sectors.

Organizational structure is a system developed by administrators to organize and coordinate the activities of an organization's members. Since environmental policies and situations vary from one organization to the other. A variety of potential organizational structures does exist. The structure of the organization can be seen as an established pattern of relationships between the organization's constituents. In organizations that are large and complex, the structure is set out by designing the major components or subsystems, and then by establishing relationships between these subsystems. It is the patterning of these relationships that is preferable to an organizational structure with some degree of permanence. In another sense, according to Naoum et al. (2015), organizational culture determines the approaches to decision-making, the standard of interaction, and professional associations. Hodges, (2005) opined those enhancements in sustainable construction do not impact the economy and environment alone, but also promote public wellbeing and protection of inhabitants to minimize pollution, emissions and waste. In this respect, in the 21st century, sustainability has become a very critical topic for the construction industry (Dobson et al., 2013).

According to Begum et al. (2007), construction waste generation in Malaysia has become one critical issue. This is a consequence of the rapid growth in the Malaysia construction industry, which contributes to the production of a lot of construction waste. If not properly treated and managed, the waste management system would have detrimental effects on humans and the environment, not just in Malaysia, but also in any part of the world. In addition, unlawful disposal of waste attitudes of contractors in the construction site is the main problem that emerges from construction waste in Malaysia. To resolve these problems, through specific construction waste regulations, Malaysia must start with the waste management hierarchy and also come up with some disposal strategies. The organizational structure in Malaysia may be one of the important techniques for the implementation of effective and productive management of construction waste which will affect the efficient management of construction waste Abulhakim and Adeleke (2019).

An important part of sustainable construction is the waste management from construction. Furthermore, waste management includes eliminating, where feasible, minimizing and reusing materials that may not become waste (Napier, 2012). He added that waste reduction, recycling and reuse in solid waste management practices have been identified as very critical for sustainable resource management. Researchers have sought to explore mechanisms of reducing energy emission and the adverse impact that project constructions can have on the environment. The organizational structure, therefore, plays an important role in the implementation of effective management of waste and in the further improvement of a company's sustainability, particularly in the construction industry. Every company must, therefore, have its own organizational structure that sought to enhance sustainable project 
construction. However, because the sustainability performance of infrastructure projects has a greater impact on society than that of regular construction projects, current literature has only given a small image of the sustainable performance of infrastructure Doni et al. (2021). While there are indications of a potential link between performance and organizational culture, none of the reports in the literature examines if there is a connection between the organizational culture of a construction firm and sustainable projects. The aim of this study is to bridge this gap. It is hypothesized that organizational culture by these companies can influence the waste management of construction firms. This perception may be beneficial to foster a correct organizational culture which can minimize waste in construction projects.

\section{LITERATURE REVIEW}

\subsection{OVERVIEW OF THE MALAYSIAN CONSTRUCTION INDUSTRY}

Construction industries, which are considered as the main stimulant to the Malaysian economy, are one of the industries that generate wealth and the growth of the country's society and economies. In Malaysia, there were many kinds of industries generating economic wealth for the nation. However, construction industries have a significant impact on the nation's economies Ismayana and Adeleke (2020). In addition, several Malaysian companies have also been active in the construction sector, providing economic strength linked to the construction industry, providing employment for construction projects and also building infrastructure that is crucial to keeping the nation moving forward. Nevertheless, since it is risky and also one of the most profitable industries in the world, the construction industry is one of the most demanding industries. In addition, according to the Department of Statistics Malaysia (2019), as reported by the Malaysian construction sector, the value of construction work performed in the fourth quarter of 2018 was RM 36.5 billion.

Moreover, 4.8\% of Malaysia's overall economic output in 2018 led to the GDP of civil engineering and advanced construction industries. (Stats Department, Malaysia). The Gross Domestic Product for construction in Malaysia is expected to be RM14727 million by the end of the last quarter of 2019, according to Trading Economics, the worldwide macro models and analytics expectations Rahman and Adeleke (2018). In addition, the construction sector in Malaysia is one of the top 5 industries with a direct contribution to Malaysia's economic growth. The construction industry was fourth in 2018, $4.8 \%$ behind the services sector, which contributed $54.8 \%$, the manufacturing sector, which accounted for $22.8 \%$, and the agriculture sector, which contributed $7.6 \%$ to Malaysia's economic results (Department of Statistics, Malaysia, 2019). In fact, the construction industry is divided into two non-residential (including three heavy manufacturing, institutional and commercial engineering sub-sectors) and residential sectors.

Environmental Waste Management (EWM, 2006) reiterated that the process for waste management consists of the reduction of materials during the design and plan- 
ning phases, the reduction of scrap and waste at the construction site, the reuse of materials on-site and the recycling of unusable materials. The principles of creative waste management strategies incorporate routines and potential solutions for conventional construction approaches, construction methods and waste disposal alternatives, and their costs and advantages are also used to tackle the project.

\subsection{ORGANIZATIONAL CULTURE}

Organizational culture is the particular arrangement of mechanisms that an organization follows when coping with different organizational challenges, jointly created by people in the organization Schein (2009), Hofstede et al. (2010). Organizational culture could be described as a framework of common principles and values that offers people expectations for organizational behavior Deshpande and Webster (1989). The fundamental and widely shared problems Hofstede et al. (2010), conundrums Trompenaars and Hampden-Turner (2000), or inconsistencies Quinn (1988) that all individuals or organizations have to contend with are embedded in the organizational culture. It is possible to manage and deliberately change organizational culture or aspects of it i.e. administrators can use culture as a leadership device Peters and Waterman (1982). Culture is a developed trait that is distinct from an individual's essential principles and personalities Hofstede et al. (2010). Therefore, when modifying an organization's culture, we resolve issues of knowledge management, i.e. the mutual training of a particular entity Vijayakumar and Padma (2014). In developing, gaining, and transmitting information, as well as changing actions to demonstrate new learning experiences, organizations that have built a strong learning culture are successful Huber (1991), Garvin (1996), Škerlavaj and Al (2007).

\subsubsection{ORGANIZATIONAL CULTURE IN CONSTRUCTION INDUSTRY}

Scholars and practitioners also recognize that the culture of organizations has a strong influence on organizations' long-term success. Nevertheless, it should be acknowledged that there is still a need for protocols, structures, or instruments that enable the organizational culture to be developed and modified as appropriate, thus improving the organization's performance Schein (2004), Trice and Beyer (1993), Cameron and Quinn (2011). The construction industry players made this issue discussion attention as they have become conscious of its essential function. Most research, however, has concentrated on the characteristics of the organizational culture of construction-related entities in various regions. For example, the organizational culture of architectural and building firms in Scotland were examined by Ankrah and Langford (2005), Jaeger and Adair (2013) addressed the organizational culture of firms engaged in construction project management in the Gulf Cooperation Council countries; the cultural profiles of architectural and construction firms in Turkey was analyzed by Oney-Yazıcı et al. (2007). Hartmann (2006) also dis- 
cussed the motivating dimensions of organizational environment on creative actions in a construction company; Yong and Pheng (2008) explored the introduction from an organizational culture viewpoint of overall value control activities; Cheung et al. (2011) researched enhancing the efficiency of construction firms from the angle of organizational culture. In order to enhance other dimensions of infrastructure, these studies have led practitioners and scholars to investigate the use of organizational culture (i.e. formalization structure and centralization structure) on construction waste management.

\subsection{CONCEPTUAL FRAMEWORK}

This research is performed with specifically described variables that are dependent and independent variables using the stated model. The independent variables are the formalization structure and centralization structure, and the dependent variable is the construction waste management structure (recycling). Thus, the structure illustrates the relationship between these variables. Therefore, the relationship between the formalization and centralization structure is deeply related to the role of organizational structure on construction waste management among Kuantan Malaysian Construction Industries.

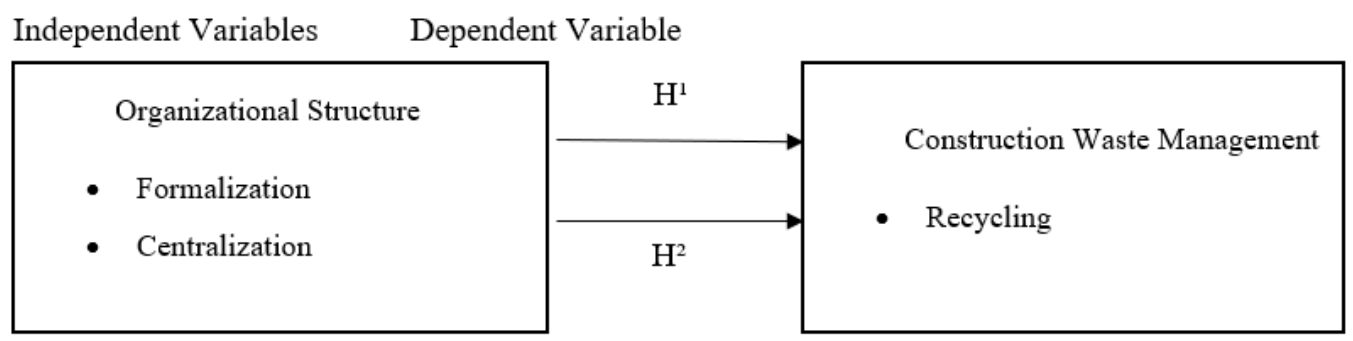

Figure 1 Conceptual Framework

\subsection{RELATIONSHIP BETWEEN FORMALIZATION STRUCTURE AND CONSTRUCTION WASTE MANAGEMENT (RECYCLING)}

According to Martin (2009), formalization is the degree to which rules and procedures are observed in an organization. The aspect differs dramatically across different organizations. For example, in every organization, arrival and departure times to and from work are defined by the minute, with time clocks used to monitor and degenerate behavior Naoum et al. (2015). It is known in various organizations that workers would spend sufficient time on the job to do the work. Most behaviors are covered by rules and procedures in a few organizations, while in others, individuals are free to exercise their judgment. In their studies, Jaworski\&Kholi (1993) defined formalization as the degree to which the organization defines laws, punishments, authority, relationships, and responsibilities, line of communications, norms 
and procedure. Fundamentally, it can be seen as a way to uphold the norms and guidelines that direct workers when achieving the objectives of the company (Auh and Menguc. 2007). In this report, Pertusa-Ortega et al. (2010) asserted that formalization is the degree to which decision-making and working relationships in construction waste management organizations are governed by formal rules and standard policies and procedures. Based on the above discourse, it is hypothesized that;

Hypothesis 1: Formalization structure positively and significantly influence construction waste management

\subsection{RELATIONSHIP BETWEEN CENTRALIZATION STRUCTURE AND CONSTRUCTION WASTE MANAGEMENT (RECYCLING}

It is said that centralization is the mechanism by which an organization's operations, mostly those related to planning and decision making, are centralized into a single place or community Pertusa-Ortega et al. (2010). Centralization is the intersection of an entity of power, decision making, and contract periods. In a centralized organization, or on the basis of pre-set policies, the top executives make decisions. These decisions or regulations are then followed by other levels of the company after the control is gradually extended until its base level is reached Pertusa-Ortega et al. (2010). Centralization was characterized by Martin and Miller (1991) as the point at which marketing planning and decision-making activities are concentrated in a few positions. In the view of the construction waste management company, a centralized structure restricts the decision-making authority of the manager and the ultimate decisionmaking power lies under the jurisdiction of the chief executive officers (CEOs) or directors. Therefore, we hypothesized that;

Hypothesis 2: There is a significant relationship between centralization structure and construction waste management

\section{METHODOLOGY}

A cross-sectional and quantitative approach is the research design adopted for this study, which is one of the famous methods used by social science researchers for their research. (Sekaran et al., 2001). In addition, the greater population of the sample is appropriate for quantitative methods. (Kaya Yilmaz, 2013). By using a wellstructured questionnaire to collect feedback from the respondent, the data was collected at a single-point-in-time. (Sekaran and bougie, 2013). Therefore, the stratified random sampling technique was employed for sample selection for this study. This research was conducted among Kuantan, Pahang construction companies and the total number of 107 samples was collected from the sample companies in Kuantan, Pahang. 


\subsection{INSTRUMENT DESIGN}

The method of data collection used in this study is questionnaires to collect the respondent's data in order to gain more information. Questionnaires are a helpful choice to consider when performing a formal survey that involves the kinds of surveys used for the data collection for this survey, including a mix of online surveys, email-based surveys, and self-administered surveys. (Nigel Mathers et al., 2006). SPSS was used to analyze the data for descriptive analysis of the demographic characteristics of the respondent, including position, year of life, gender, prime location of the company, owners of the company, job experience, number of full-time employees and ownership of the company. To evaluate the data for the relationship between the independent and dependent variables, SmartPLS version 3.0 was also used. In addition, the five-point Likert scale ranging from 1 (strongly disagree), 2 (disagree), 3 (neutral), 4 (agree) and 5 (strongly agree) was also used to measure the independent and dependent variable elements in order to obtain the respondents' input. The questionnaire items were adapted from Kamaruddeen (2011) and were all in English.

\section{RESULTS}

\subsection{DATA COLLECTION AND SAMPLE}

107 sets of questionnaires were distributed to the construction companies in Kuantan, Pahang. Table 1 shows a summary of the demographic characteristics of respondents for this study Kanimoli et al. (2020).

Table 1 Profile of Respondent

\begin{tabular}{lll}
\hline Demographic & Count & Percentage \\
\hline Gender & 35 & $32.71 \%$ \\
\hline Female & 72 & $67.29 \%$ \\
\hline Male & & \\
\hline Construction Entity & 2 & $1.87 \%$ \\
\hline International & 105 & $98.13 \%$ \\
\hline Local & & \\
\hline Experienced In Industry & 52 & $48.60 \%$ \\
\hline 1-3 years & 46 & $42.99 \%$ \\
\hline $4-6$ years & 9 & $8.41 \%$ \\
\hline 7-9 years & & \\
\hline Position In Company & 9 & $8.41 \%$ \\
\hline Architect & 1 & $0.93 \%$ \\
\hline clerk & 24 & $22.43 \%$ \\
\hline Contract Manager & 10 & $9.35 \%$ \\
\hline Contractor & 20 & $18.69 \%$ \\
\hline Engineer & 14 & $13.08 \%$ \\
\hline Project Manager & 22 & $20.56 \%$ \\
\hline Safety Officer & 5 & $4.67 \%$ \\
\hline Site Manager & 2 & $1.87 \%$ \\
\hline Technician & &
\end{tabular}


Table 1 continued

\begin{tabular}{|lll|}
\hline Category of Contractors & & \\
\hline Building Construction & 29 & $27.10 \%$ \\
\hline Civil Engineering & 40 & $37.38 \%$ \\
\hline Facility Management & 12 & $11.21 \%$ \\
\hline Mechanical and Electrical & 26 & $24.30 \%$ \\
\hline Company Prime Location & & \\
\hline Across Malaysia & 10 & $9.35 \%$ \\
\hline International & 1 & $0.93 \%$ \\
\hline Local market area & 94 & $87.85 \%$ \\
\hline Within a few State & 2 & $1.87 \%$ \\
\hline Company been in Existence & & \\
\hline$>10$ years & 8 & $7.48 \%$ \\
\hline $1-3$ years & 14 & $13.08 \%$ \\
\hline $4-6$ years & 56 & $52.34 \%$ \\
\hline $7-9$ years & 29 & $27.10 \%$ \\
\hline The Number of Full Time & & \\
\hline \multicolumn{1}{c}{ Employees Company } & & \\
\hline$>151$ & 25 & $23.36 \%$ \\
\hline $0-50$ & 10 & $9.35 \%$ \\
\hline $101-150$ & 46 & $42.99 \%$ \\
\hline $51-100$ & 26 & $24.30 \%$ \\
\hline
\end{tabular}

\subsection{MEASUREMENT MODEL}

The measurement model and the outer model were evaluated via the partial least square structural equation modeling (PLS-SEM) approach before testing the hypothesis. The model of this research with the structural dimensions below is shown inFigure 2 .

Convergent validity is defined to be the degree to which a set of variables converges in order to calculate a particular term. In order to ensure that the construct validity is associated, convergent validity is an essential part of validity. Therefore, three parameters were all calculated at once to evaluate the convergent analysis especially the factor loadings, composite reliability (CR) and average variance extracted (AVE). Moreover, all loading items were checked, which is appropriate for all items. Then, following the literature of the multivariate method, its values need to be more than 0.5 . In addition, the other criterion for testing convergent validity is composite reliability (CR). Sabodin and Adeleke (2018).

Table 2 Convergent Validity

\begin{tabular}{|c|c|c|c|c|c|c|}
\hline Construı & $\begin{array}{l}\text { Item } \\
\text { Code }\end{array}$ & Item & $\begin{array}{c}\text { Outer } \\
\text { Load- } \\
\text { ing }\end{array}$ & AVE & CR & $\begin{array}{l}\text { Cronbach' } \\
\text { Alpha }\end{array}$ \\
\hline CS & CS1 & $\begin{array}{c}\text { There are opportunities available to express } \\
\text { our ideas to upper management. }\end{array}$ & 0.814 & 0.649 & $0.96 !$ & 0.961 \\
\hline & CS10 & $\begin{array}{l}\text { There is an open door policy foe } \\
\text { communication in this organization. }\end{array}$ & 0.827 & & & \\
\hline
\end{tabular}

Continued on next page 


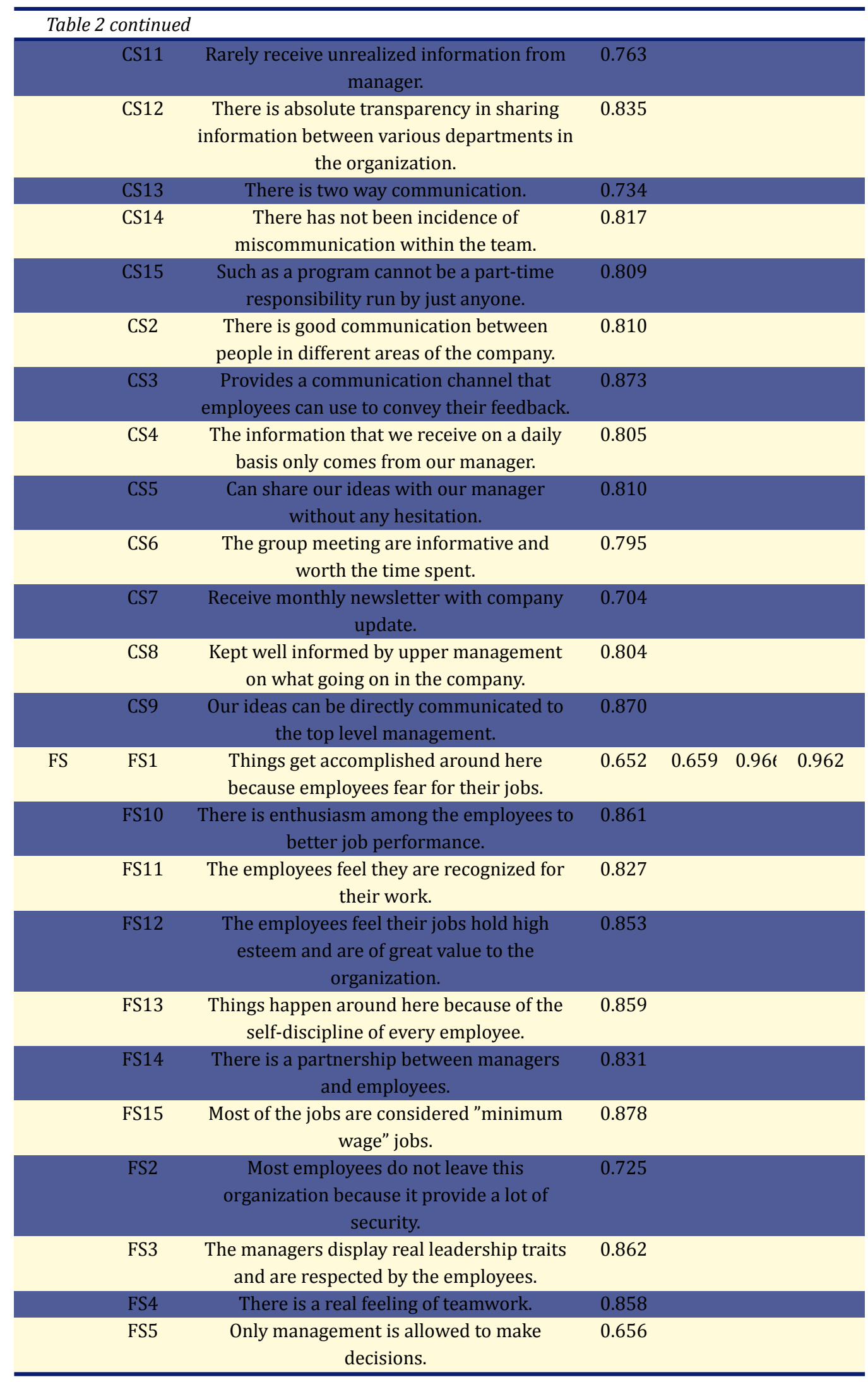




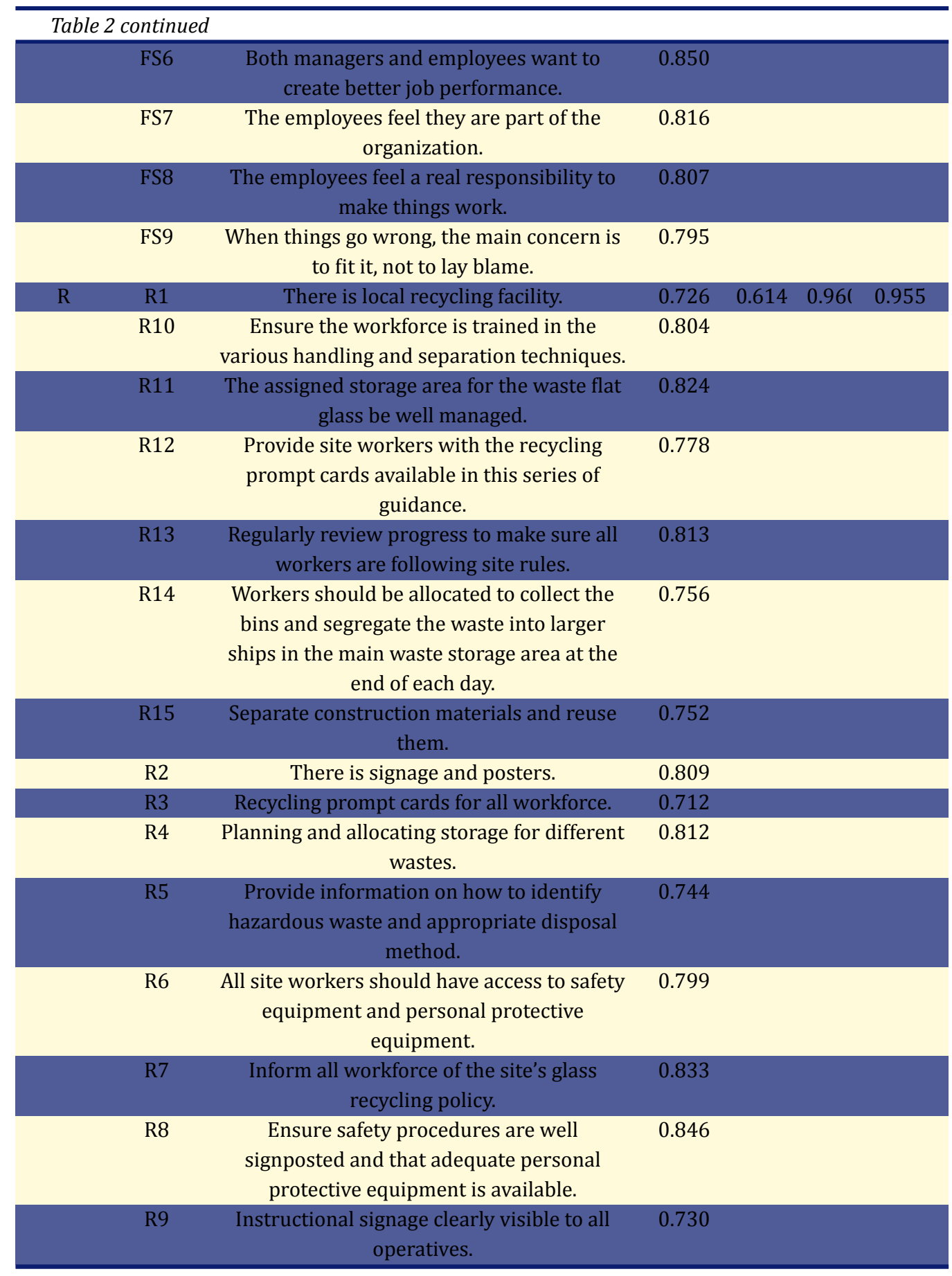

Discriminant validity is necessary for the construct validity of the outer model. Before the hypothesis is investigated through path analysis, the discriminant validity is mandatory to be checked. The assessment showed that the degree to which products vary between constructs differs. Then the discriminant validity showed that various structures used by objects do not overlap. As shown in Table 3 , the diagonal elements of the correlation matrix were replaced with the square root of AVE for all constructs. Therefore, where the diagonal elements in the table were greater than the other elements in the column and row where they are placed, the discriminant 


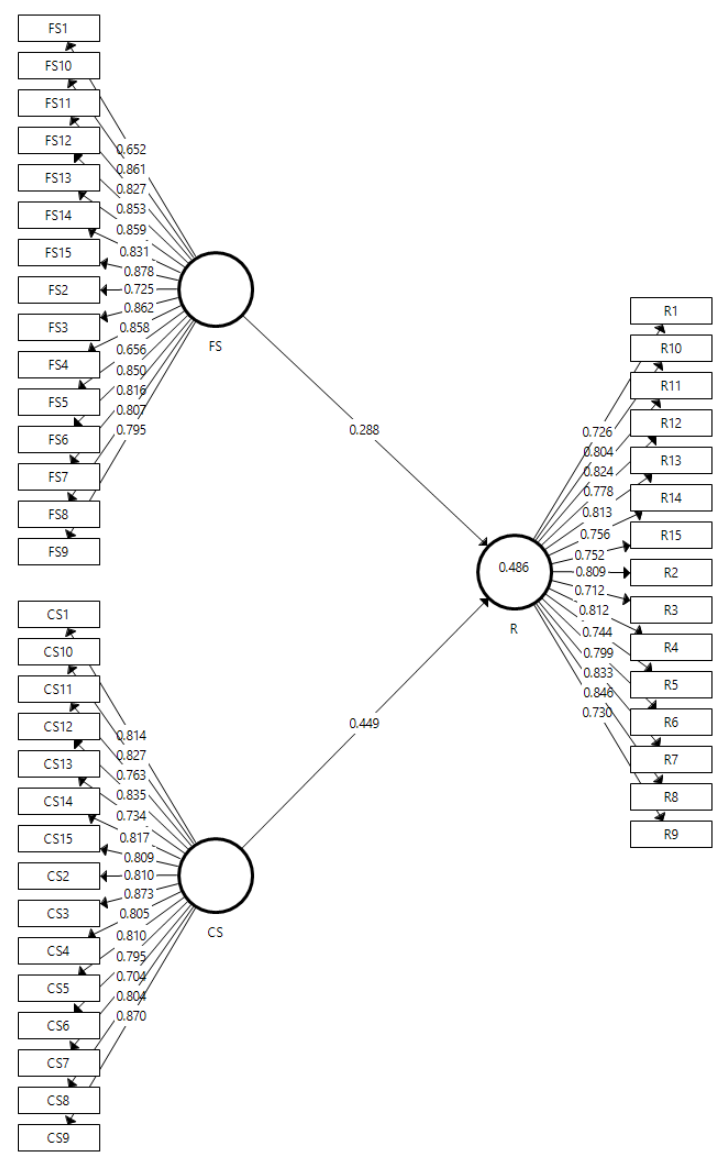

Figure 2 Measurement Model

validity of the outer model for this research was confirmed. From the above testing for the construct validity of the outer model, it is assumed that the hypothesis test results obtained should be highly reliable and accurate. Ismayana and Adeleke (2020).

\begin{tabular}{cccc}
\hline $\begin{array}{l}\text { Table } 3 \\
\text { Validity }\end{array}$ & Discriminant \\
\hline & CS & FS & R \\
CS & & & \\
FS & 0.802 & & \\
R & 0.679 & 0.624 & \\
\hline
\end{tabular}

In this analysis, bootstrapping techniques are embedded with SmartPLS 3 to infer whether or not the path coefficients are statistically significant. The T-values were calculated for each path coefficient using the bootstrapping technique, as stated in Table 7 , and the P-values were subsequently generated. As suggested in Hypothesis 1 , the findings indicate that there is a strong relationship between these CS-R vari- 
ables $(\beta=0.449, \mathrm{t}=5.071$, P-Values $=0.000)$. Hypothesis 2 was also supported which shows that there is a significant relationship between centralization structure and recycling effectiveness with FS $-\mathrm{R}(\beta=0.288, \mathrm{t}=2.973$, P-Values $=0.002)$. So, both variables have a significant relationship on construction waste management among Kuantan, Pahang Malaysian construction industries Samsudin et al. (2020), Jamil and Adeleke (2018).

\begin{tabular}{cccccccccc}
\hline \multicolumn{2}{l}{ Table 4} & \multicolumn{2}{l}{ Summary of Hypotheses Testing } \\
\hline Hypoth & Path & $\begin{array}{c}\text { Standard } \\
\text { Beta }\end{array}$ & $\begin{array}{l}\text { Standard } \\
\text { Deviation }\end{array}$ & $\begin{array}{l}\text { T } \\
\text { Statis- } \\
\text { tics }\end{array}$ & $\begin{array}{l}\text { P } \\
\text { Val- } \\
\text { ues }\end{array}$ & Bias & $\mathbf{5 . 0 0 \%}$ & $\mathbf{9 5 . 0 0 \%}$ & Decision \\
H1 & $\begin{array}{c}\text { CS } \\
\text { - R R }\end{array}$ & 0.449 & 0.089 & 5.071 & 0.000 & 0.008 & 0.298 & 0.580 & Supported \\
H2 & FS & 0.288 & 0.097 & 2.973 & 0.002 & 0.003 & 0.129 & 0.433 & Supported \\
\hline
\end{tabular}

Note: $\mathrm{p}<0.05$

$\mathrm{R}^{2}$ values showing the endogenous variable contribution of exogenous variables were also assessed. The $\mathrm{R}^{2}$ values is 0.486 .

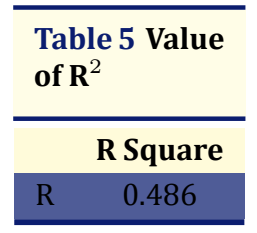

For multiple independent variables, $\mathrm{f}^{2}$ was carried out on a dependent variable, which is used to test the changes in $\mathrm{R}^{2}$ in an effort to understand whether or not of particular independent latent construct and dependent latent construct has a practical impact (Cohen 1988).

\begin{tabular}{|c|c|c|c|}
\hline \multicolumn{4}{|c|}{ Table 6 Value of $f^{2}$} \\
\hline & CS & FS & $\mathbf{R}$ \\
\hline $\mathrm{CS}$ & & & 0.153 \\
\hline FS & & & 0.063 \\
\hline $\mathrm{R}$ & & & \\
\hline
\end{tabular}

In particular, the $Q^{2}$ statistic of 0.27 was confirmed in the results. The predictive validity of the model is defined for the endogenous latent variable of this analysis, which is greater than zero. 


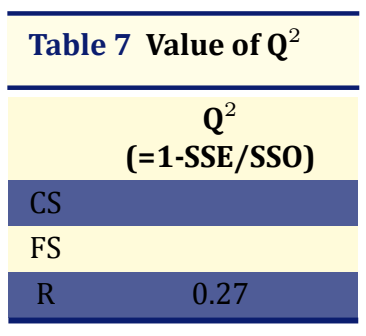

\section{DISCUSSION}

This research was intended to explore the relationship between organization structure (e.g. formalization structure and centralization structure) on construction waste management among Kuantan Malaysian construction industries. By recognizing the relationship, it provides tools and insight for organizations and academics to continue enhancing the management of building waste to minimize the occurrence of waste in construction projects. The first objective in this study is to evaluate the significant relationship between formalization structure and recycling effectiveness among Kuantan Malaysian Construction industries. From the result, it shows that formalization structure has a positive relationship with recycling effectiveness. The second objective is to assess the significant relationship between centralization structure and recycling effectiveness among Kuantan Malaysian Construction industries. As a result, it illustrates that the structure of centralization has a positive relationship with the effectiveness of recycling. In the view of the construction waste management company, a centralized structure restricts the decision-making authority of the manager and the ultimate decision-making power lies under the jurisdiction of the Chief Executive Officers (CEO) or directors.

\section{IMPLICATIONS}

\subsection{THEORETICAL IMPLICATIONS}

Theoretically, this study has implications on filling the knowledge vacuum between organizational culture constructs i.e. formalization and centralization on sustainable construction management. . Many similar studies have been carried out to show that the position of the organizational structure has an impact on the management of construction waste, thereby providing better or true results. This research was also applied to parties interested in the construction industry to assess the reliability of the IV's and DV's in this study, which will enhance the academic stability of the study. In addition, because of the lack of research among employees employed at one of the companies in the industry in Malaysia, this study would be worthy and contribute value to the academic world. 


\subsection{PRACTICAL IMPLICATIONS}

The study on construction waste management is not only important to the academic world, but also to the employer in every construction industry who needs the management of waste. To promote the successful adoption of sustainability, managers are expected to consider the principles and customs emphasized in their organizations. Furthermore, appropriate organizational culture and leadership help to increase the performance of the company. Similarly, the most critical feature of the construction industry in recent years has been positive performance in improving the management of construction waste in the construction industry. Moreover, it can also assist the industry to optimize its profit goals. In order to set up a waste management plan, parties in the construction industry may use the data found in this study. The contribution made by this research is both theoretical and practical, where the theoretical contribution to this study is the incorporation of existing literature on formalization and construction waste management, centralization and construction waste.

\section{CONCLUSION}

This study focused on formalized and centralized organizational structure as an element of organizational structure on construction waste management in Pahang Malaysian construction industries. Therefore, this study is important for the stakeholder who works in construction industries especially the industries without effective construction waste management practices to improve the effective construction waste management. The study concludes that the prevailing perceptions of the participants are that sustainable buildings generate significant comfort conditions, well-being, fitness, efficiency and psychological wellness of inhabitants with relation to human benefits. Besides, this study is one of the few studies that examine the effects of organizational structure on construction waste management Practically, this research can be of benefits to the employer such as managers, engineers, quantity surveyors and so on who are working on construction projects in the construction industries. Therefore, the future researcher can be explored to investigate a decentralized organizational structure or any other organizational structure elements on construction waste management and empirically validate the proposed model in this study.

\section{ACKNOWLEDGEMENT}

We would like to thank Universiti Malaysia Pahang for the financial assistance through research grants with RDU190390. 


\section{REFERENCES}

Abulhakim, N., \& Adeleke, A. Q. (2019). The Factors Contributing To Accident Occurrence On Malaysia Building Projects Through Partial Least Square Structural Equation Modeling. Social Science And Humanities Journal, 1096-1106.

Ankrah, N. A., \& Langford, D. A. (2005). Architects and contractors: a comparative study of organizational cultures. Construction Management and Economics, 23(6), 595607. Retrieved from https://dx.doi.org/10.1080/01446190500126973 10.1080/ 01446190500126973

Begum, R. A., Siwar, C., Pereira, J. J., \& Jaafar, A. H. (2007). Implementation of waste management and minimisation in the construction industry of Malaysia. Resources, Conservation and Recycling, 51, 190-202. Retrieved from https://dx.doi.org/10.1016/j .resconrec.2006.09.004 10.1016/j.resconrec.2006.09.004

Cameron, K. S., \& Quinn, R. E. (2011). Diagnosing And Changing Organizational Culture: Based On The Competing Values Framework. San Francisco, CA, USA: John Wiley And Sons.

Cheung, S. O., Wong, P. S. P., \& Wu, A. W. Y. (2011). Towards An Organizational Culture Framework In Construction. Int. J. Proj. Manag, 29(1), 33-44. Retrieved from Http:// Dx.Doi.Org/10.1016/J.Ijproman.2010.01.014

Deshpande, R., \& Webster, F. E. J. (1989). Organizational Culture And Marketing: Defining The Research Agenda”. Journal Of Marketing, 53(1), 3-15. 10.2307/1251521

Doni, N. H., Adeleke, A. Q., \& Ismail, A. I. (2021). Organizational Culture and its Influence on Sustainable Construction among Johor Malaysian Construction Industries. International Journal of Research Publications, 73, 11-11. Retrieved from https://dx.doi.org/ 10.47119/ijrp100731320211810 10.47119/ijrp100731320211810

Fredrickson, J. W. (1986). The Strategic Decision Process and Organizational Structure. Academy of Management Review, 11(2), 280-297. Retrieved from https://dx.doi.org/ 10.5465/amr.1986.4283101 10.5465/amr.1986.4283101

Garvin, D. A. (1996). Building The Learning Organization. Harvard Business Review. 10.1017/ CB09781107415324.004

Gregory, B. T., Harris, S. G., Armenakis, A. A., \& Shook, C. L. (2009). Organizational culture and effectiveness: A study of values, attitudes, and organizational outcomes. Journal of Business Research, 62(7), 673-679. Retrieved from https://dx.doi.org/10.1016/ j.jbusres.2008.05.021 10.1016/j.jbusres.2008.05.021

Hofstede, G., Hofstede, G. J., \& Micheal, M. (2010). Cultures And Organizations - Software Of The Mind, Revised And Expanded 3rd Ed. New York, NY: Mcgraw-Hill.

Huber, G. P. (1991). Organizational Learning: The Contributing Processes And The Literatures. Organization Science, 2(1). 10.1287/Orsc.2.1.88

Ismayana, M. P., \& Adeleke, A. Q. (2020). The Influence Of Organizational Culture On Construction Risk Management Among Kuantan Malaysian Construction Industry: A Partial Least Square Structural Equation Modeling Approach. Social Science And Humanities Journal, 1693-1704.

Jaeger, M., \& Adair, D. (2013). Organizational Culture Of Construction Project Managers In The GCC. Countries. Eng. Constr. Archit. Manag, 20(5), 461-473. Retrieved from //Dx .Doi.Org/10.1108/ECAM-01-2012-0004

Jamil, N., \& Adeleke, A. Q. (2018). The Relationship Between Team Competency And Design Risk Management Among Construction Industries In Kuantan. Journal Of Advanced Research In Applied Sciences And Engineering Technology, 10(1), 77-81.

Kanimoli, A., Adeleke, A. Q., \& Taiwo, T. T. (2020). Organizational Structure Influence On 
Construction Waste Management Among Penang Malaysian Construction Industry: An Approach Via Partial Least Square Structural Equation Modeling. Journal of Business Management and Economic Research, 4(1), 56-73. Retrieved from https://dx.doi.org/ $10.29226 / \operatorname{tr} 1001.2020 .18310 .29226 / \operatorname{tr} 1001.2020 .183$

Liu, A. M., Shuibo, Z., \& Meiyung, L. (2006). A framework for assessing organisational culture of Chinese construction enterprises. Engineering, Construction and Architectural Management, 13, 327-342. Retrieved from https://dx.doi.org/10.1108/ $0969998061068015310.1108 / 09699980610680153$

Martin, C., \& Miller, J. (1991). Discrete obsevability of nonlinear systems using continuation techniques. In Applied Mathematics and Computation (Vol. 44, pp. 241-248). San Francisco: Elsevier BV. Retrieved from https://dx.doi.org/10.1016/0096-3003(91)90060 -z 10.1016/0096-3003(91)90060-z

Naoum, S. G., Alyousif, A.-R. T., \& Atkinson, A. R. (2015). Impact of National Culture on the Management Practices of Construction Projects in the United Arab Emirates. Journal of Management in Engineering, 31(4), 04014057-04014057. Retrieved from https://dx.doi.org/10.1061/(asce)me.1943-5479.0000265 10.1061/(asce)me.1943 $-5479.0000265$

Nukic, I. S. (2018). Organizational Culture As A Determinant Of Construction Companies' Competitiveness: Case Study Of Croatia.

Oney-Yazıcı, E., Giritli, H., Topcu-Oraz, G., \& Acar, E. (2007). Organizational culture: the case of Turkish construction industry. Engineering, Construction and Architectural Management, 14(6), 519-531. Retrieved from https://dx.doi.org/10.1108/ 09699980710828996 10.1108/09699980710828996

Pertusa-Ortega, E. M., Zaragoza-Sáez, P., \& Claver-Cortés, E. (2010). Can formalization, complexity, and centralization influence knowledge performance? Journal of Business Research, 63(3), 310-320. Retrieved from https://dx.doi.org/10.1016/j.jbusres.2009 .03 .015 10.1016/j.jbusres.2009.03.015

Peters, T. J., \& Waterman, R. H. (1982). Search Of Excellence. 10.1891/0730-0832.30.6.369

Quinn, R. E. (1988). Beyond Rational Management: Mastering Paradoxes And Competing Demands Of High Performance. London: Jossey-Bass.

Rahman, N. F. A., \& Adeleke, A. Q. (2018). The Relationship Between Effective Communication And Construction Risk Management Among Kuantan Malaysian Construction Industries. Journal of Advanced Research In Applied Sciences And Engineering Technology, 10(1), 18-24.

Sabodin, N., \& Adeleke, A. Q. (2018). The Influence Of Government Regulation On Waste Reduction Among Kuantan Malaysian Construction Industry. Journal of Advanced Research In Applied Sciences And Engineering Technology, 10(1), 72-76.

Samsudin, N. S. A., Adeleke, A. Q., \& Ajibike, W. A. (2020). Effects Of Contractors' Delay Factors On Building Project Performance Among Kuantan Malaysian Construction Industry. Social Science And Humanities Journal, 1705-1715.

Schein, E. H. (2004). Organizational Culture And Leadership John Wiley \& Sons, San Francisco; CA; USA.

Schein, E. H. (2009). The Corporate Culture Survival Guide, John Wiley Trade.

Sekaran, U., \& Bougie, R. (2016). Research Methods For Business: Skill-Building Approach.

Trice, H. M., \& Beyer, J. M. (1993). The Cultures Of Work Organizations. Englewood Cliffs, NJ; USA: Prentice- Hall.

Trompenaars, F., \& Hampden-Turner, C. (2000). Riding The Waves Culture: Understanding 
Cultural Diversity In Business. London: Nicholas Brealey Publishing.

Vijayakumar, V. S. R., \& Padma, R. N. (2014). Impact of perceived organizational culture and learning on organizational identification. International Journal of Commerce and Management, 24(1), 40-62. Retrieved from https://dx.doi.org/10.1108/ijcoma-01-2012 -0003 10.1108/ijcoma-01-2012-0003

Škerlavaj, M. E., \& Al. (2007). Organizational Learning Culture-The Missing Link Between Business Process Change And Organizational Performance". International Journal of Production Economics, 106(2), 346-367. 10.1016/J.Ijpe.2006.07.009

Yong, K. T., \& Pheng, L. S. (2008). Organizational culture and TQM implementation in construction firms in Singapore. Construction Management and Economics, 26(3), 237248. Retrieved from https://dx.doi.org/10.1080/01446190701874397 10.1080/ 01446190701874397

Yusuf, N., Kamaruddeen, A. M., \& Bahaudin, A. Y. (2016). Moderating Effect of Government Policy On The Relationship Between Organizational Structure And Construction Waste Management. Rev. Téc. Ing. Univ. Zulia, 39(1), 88-100. 